\title{
Effects of different cutting heights on coppice response of forage shrubs in Ghana
}

\author{
Ziblim Abukari Imoro ${ }^{a}\left(\mathbb{D}\right.$, Oppong Samuel Kingsleyb ${ }^{\mathrm{b}}$, Ammal Abukari ${ }^{\mathrm{c}, *}$ (i)
}

\begin{abstract}
This study aimed to determine the effect of cutting intensity on the recovery rate, growth, and biomass production of selected savanna forage shrub species. The study was conducted at the University for Development Studies (UDS), Nyankpala Campus in the Tolon District of the Northern Region of Ghana. Cajanus cajan, Stylosanthes mucronata, Tephrosia purpureum and Securinega virosa were cut at $15 \mathrm{~cm}, 30 \mathrm{~cm}$, and $60 \mathrm{~cm}$ above ground level a month after a standardizing cut and number of days to sprout, the number of shoots, plant height, and root collar diameter was recorded. The experiment was a randomized complete block design with four replications. Shrubs cut at $60 \mathrm{~cm}$ used less mean number of days (4.25) for sprouting and those cut at $15 \mathrm{~cm}$ took a longer period (4.92) to sprout. Plant height, number of shoots, and root collar diameter after cutting were highest for shrubs cut at $60 \mathrm{~cm}$. Securinega virosa used less mean number of days (4.00) to sprout while $S$. mucronata used the highest mean number of days (5.44) after cutting. Total dry matter yield was significantly highest ( $123.90 \mathrm{~g} / \mathrm{plant})$ for shrubs cut at $60 \mathrm{~cm}$ but lowest for those cut at $15 \mathrm{~cm}(91.20 \mathrm{~g} / \mathrm{plant})$. Cajanus cajan recorded a significantly higher total dry matter (116.30 g/plant) while $S$. virosa had the lowest $(93.00 \mathrm{~g} / \mathrm{plant})$. Our results suggest that cutting height significantly influences the rate of sprouting of shrubs after cutting, and the response to the cutting effect is species-dependent
\end{abstract}

Keywords: Coppice, Cutting height, Dry matter, Shrub, Sprout

\section{Gana'daki yem çalılarının baltalık tepkisi üzerine farklı kesme yüksekliklerinin etkileri}

\begin{abstract}
Özet: Bu çalışmada, seçilen savana yem çalısı türlerinin geri kazanım oranı, büyümesi ve biyokütle üretimi üzerine kesme yoğunluğunun etkisini belirlemek amaçlanmıştır. Çalışma, Kalkınma Araştırmaları Üniversitesi'nin (UDS: University for Development Studies) Gana'nın kuzeyinde Tolon Bölgesi'nde yer alan Nyankpala Kampüsü'nde gerçekleștirilmiştir. Cajanus cajan, Stylosanthes mucronata, Tephrosia purpureum ve Securinega virosa çalıları standart kesimden bir ay sonra, zemin seviyesinden $15 \mathrm{~cm}, 30 \mathrm{~cm}$ ve $60 \mathrm{~cm}$ yükseklikten kesilmiş ve filizlenen gün sayısı, sürgün sayısı, bitki boyu ve kök boğazı çapı kaydedilmiştir. Deneme, tesadüf blokları deneme desenine göre dört tekerrürlü olarak yapılmıştır. Filizlenme için $60 \mathrm{~cm}$ 'den kesilen çalılarda daha az ortalama gün sayısı (4.25) gerekirken, $15 \mathrm{~cm}$ 'den kesilenler ise daha uzun süre (4.92) gerekmiştir. Bitki boyu, sürgün sayısı ve kesim sonrası kök boğazı çap1 $60 \mathrm{~cm}$ 'den kesilen çalılar için en yüksek değerleri vermiştir. Securinega virosa en az ortalama gün sayısında (4.00) filizlenirken, S. mucronata ise kesimden sonra en yüksek ortalama gün sayısında (5.44) filizlenmiştir. Toplam kuru madde verimi, $60 \mathrm{~cm}$ 'den kesilen çalılar için en yüksek (123.90 g/bitki), $15 \mathrm{~cm}$ 'den kesilenler için en düşük (91.20 g/bitki) bulunmuştur. Cajanus cajan önemli ölçüde daha yüksek toplam kuru madde (116.30 g/bitki) değerine sahip iken, $S$. virosa en düşük (93.00 g/bitki) değere sahiptir. Sonuçlar, kesim yüksekliğinin kesmeden sonra çalıların filizlenme oranını önemli ölçüde etkilediğini ve kesme etkisine verilen yanıtın türe bağlı olduğunu göstermektedir.

Anahtar kelimeler: Baltalık, Kesim yüksekliği, Kuru madde, Çalı, Filiz
\end{abstract}

\section{Introduction}

In response to the increasing population, rising income, and urbanization, the demand for livestock products such as meat and milk is proliferating in sub-Saharan Africa (Kebebe, 2019). This increasing demand for livestock products offers farmers the opportunity to use livestock as a conduit out of poverty and food insecurity. To meet the growing demand, farmers must increase animals' productivity by increasing the productivity of feed from indigenous resources (IAEA, 2010).

Smallholder livestock farmers in developing countries face numerous feed constraints such as inadequate feed quality and quantity, poor storage facilities for feed conservation, and insufficient water supply (Belay et al., 2013). However, livestock feeding continues to pose many problems due to a lack of information on the composition and utilization of locally available feed resources. Forage shrubs can act as standing fodder banks to buffer seasonal

\footnotetext{
$\triangle$ a Department of Biodiversity Conservation and Management, University for Development Studies, Tamale, Ghana

b Department of Wildlife and Range Management, Kwame Nkrumah University of Science and Technology, Kumasi, Ghana

c Department of Forestry and Forest Resources Management, University for Development Studies, Tamale, Ghana

@ * Corresponding author (İletişim yazarı): aammal@uds.edu.gh

$\checkmark \quad$ Received (Geliş tarihi): 11.05.2021, Accepted (Kabul tarihi): 13.09.2021
}

Citation (Atıf): Imoro, Z.A., Kingley, O.S., Abukari, A., 2021. Effects of different cutting heights on coppice response of forage shrubs in Ghana. Turkish Journal of Forestry, 22(3): 186191. DOI: $10.18182 /$ tjf. 934994 
fluctuations that occur in arid and semi-arid areas, a protein supplement for livestock on poor native rangelands a means of soil erosion control, and a fuel source for low-income farmers.

The levels of apical dominance differ from one plant species to another (Dun et al., 2006) and affect the number of shoots forming lateral buds. The length of lateral shoots emerged and the angle of emergence (Allanah and Lonnie, 1998). The removal of apical buds of woody species either by grazing or by clipping encourages the lateral buds' activation to yield new twigs (Hélio et al., 2019). The intensity, frequency, and season of clipping influence shrubs' response to cutting (George, 2015). However, an increase in the total yield of plants after clipping is not due to the rise of the plant's woody portion but the ratio of leaves: stems (Parissi and Nastis, 2004), which affects the quality of foliage produced (Iqbal et al., 2015).

The influence of cutting height and frequency on yield and nutritional quality of forage from many browse plants has not been consistent. Responses of plants to cutting generally happen in a range of stump height, lower or higher than which cutting height has no effect on yield and forage quality (Oppong, 2008). According to Stur et al. (1994) and Pathak et al. (1980), cutting height generally exhibited little or no significant effect on forage yield but frequency did. Studies involving Leucaena leucocephala revealed no effect on leaf yield of cutting heights of $1.5-2.5 \mathrm{~m}$ above ground (Catchpole and Blair, 1990).

However, a positive relationship was reported between cutting height and yield (Krishna and Mundegowda, 1982). A report on Gliricidia sepium revealed that lower cutting heights $(30 \mathrm{~cm})$ yielded greater dry matter than those cut at higher heights $(50 \mathrm{~cm}$ and $70 \mathrm{~cm}$ ) (Tarawali et al. 1996). On Amaranthus, Zinati (2001) reported that cutting the main plant stem at $30 \mathrm{~cm}$ and $50 \mathrm{~cm}$ above ground resulted in reduced total biomass yield. In contrast, clipping at $90 \mathrm{~cm}$ height gave higher biomass. Sesbania grandiflora cannot endure repeated clipping, while others may not tolerate a very low cutting height (Ella et al. 1989). Moderate cutting triggered more new leaves production than plants clipped lightly (Parissi and Nastis, 2004; Alados et al., 1997).

Several researchers found higher cutting heights to produce higher dry matter yield (Blair et al., 1990; Costa and Oliveira, 1992; Hairiah et al., 1992). Plant loss will be curtailed with appropriate plant cutting height, apical buds triggered and thus facilitating faster regrowth rate (Bassiri et al., 2010). This study aimed to determine the effect of cutting intensity on the recovery rate, growth, and biomass production of selected savanna forage shrub species.

\section{Material and method}

A field experiment was conducted at the experimental farm of the Faculty of Natural Resources and Environment, University for Development Studies (UDS), Nyankpala Campus in the Tolon District of the Northern Region of Ghana. This area is located within the savanna ecosystem on latitude $09^{\circ} 25^{\prime} \mathrm{N}$ and longitude $00^{\circ} 55^{\prime} \mathrm{W}$ and with an altitude of $183 \mathrm{~m}$ above sea level. Nyankpala Campus is 16 $\mathrm{km}$ (10 miles) away from Tamale, the capital of the Northern Region. The area experiences an annual rainfall of about $1,034 \mathrm{~mm}$ from April to early November with a mean monthly temperature of $22{ }^{\circ} \mathrm{C}$. A maximum monthly relative humidity value of $80 \%$ can be recorded during the rainy season, while a minimum monthly value of $42 \%$ during the dry season is observed. The vegetation is guinea savanna with grasses as the dominant plant species and interspersed with economic but drought-resistant trees such as Vitellaria paradoxa, Adansonia digitata, and Tamarindus indica. The soils are well-drained with low nitrogen content due to the low organic matter cover (Ziblim et al., 2016).

Four selected indigenous forage shrub species viz, Cajanus cajan, Securinega virosa, Stylosanthes mucronata and Tephrosia purpurea were considered for the experiment. These species were chosen because of their productivity, availability, familiarity, palatability to animals, and farmers' preference in the study area. The experiment employed a randomized complete block design with four replications and plots of sizes $4 \mathrm{~m} \times 4 \mathrm{~m}$. Experimental treatments were combinations of 3 cutting heights $(15 \mathrm{~cm}, 30 \mathrm{~cm}$, and $60 \mathrm{~cm})$ for all the species from ground level. Observations on the plants' morphological growth were made every two (2) weeks for twelve (12) weeks on four (4) randomly selected plants from each species on each plot with assigned numbers. Each plot contained sixteen (16) plants. In selecting the sample plants, border plants were not considered to avoid border effects, and the selection was done using random numbers. Recovery rate, rate of vegetative growth, and dry matter yield were determined after cutting. When the plants were completely established after sowing in the $4 \times 4$ plots, a standardizing cut was made at the height of $25 \mathrm{~cm}$ from the soil. Thirty days later, all sample plants were cut to their planned target cutting heights $(15 \mathrm{~cm}, 30 \mathrm{~cm}$, and $60 \mathrm{~cm})$ and observations commenced. Parameters such as rate of recovery (which was done by observing the appearance of new vegetative parts after cutting), number of new shoots observed, the height of lead shoot, and the shrubs' root collar diameter were considered.

Dry matter yield was estimated from four representative plants of each shrub at $15 \mathrm{~cm}, 30 \mathrm{~cm}$, and $60 \mathrm{~cm}$. The dry matter yield estimation was carried out by uprooting each shrub's representative plants using the destructive technique. The sample plants were separated into leaf, stem, and root fractions. Fresh weights were taken directly and later ovendried to a constant weight at $80^{\circ} \mathrm{C}$ for 48 hours to determine dry matter yield. The fodder yield per plant was divided by the total aboveground biomass and multiplied by 100 to estimate the percent fodder (Larbi et al., 2009). Total biomass was calculated by adding the oven-dried weights of the three fractions.

Data gathered on the recovery rate of the shrubs after cutting were analyzed by descriptive statistics using percentages and means and the results presented in tables. Analysis of variance (ANOVA) was carried out to test the different cutting heights on the dry matter yield of the shrubs using Genstat software (Release 10.3 DE 2011). Differences among mean values were compared by Fisher's protected Least Significant Difference Test at 5\% probability. Graphs were used to show the effects of the cutting heights on the growth of the shrubs.

\section{Results}

The data obtained from the study showed that recovery rate was species-dependent where Securinega virosa and $T$. purpurea used significantly $(\mathrm{p}<0.001)$ less number of days to sprout compared to $C$. cajan and $S$. mucronata although $C$. cajan used less number of days to sprout compared to $S$. 
mucronata. Cutting height had significant $(\mathrm{p}<0.05)$ effect on the recovery rate of the shrubs. Shrubs cut at $60 \mathrm{~cm}$ used significantly a smaller number of days to sprout compared to those cut at $15 \mathrm{~cm}$, but there was no significant difference (p>0.05) between plants cut at $30 \mathrm{~cm}$ and $60 \mathrm{~cm}$ (Table 1). Generally, shrubs cut at $60 \mathrm{~cm}$ and $30 \mathrm{~cm}$ attained the highest mean plant height after cutting in all the shrubs (Fig. 1). Shrubs cut at $15 \mathrm{~cm}$ significantly witnessed the least number of coppice shoots (Fig. 2). Nevertheless, it was also observed that shrubs cut at $60 \mathrm{~cm}$ had bigger root collar diameter and cutting height at $15 \mathrm{~cm}$ recorded the least (Fig. 3).

On the individual shrub responses, $S$. mucronata registered the highest number of coppice shoots at all the cutting heights while $S$. virosa recorded the lowest (Fig. 2).

$C$. cajan and $S$. mucronata had greater root collar diameter particularly at $60 \mathrm{~cm}$ compared to $T$. purpurea and S. virosa (Figure 3). The different cutting heights significantly $(\mathrm{p}<0.05)$ influenced the growth of the root collar diameter except for $T$. purpurea where no significant difference in root collar diameter was observed between plants cut at $15 \mathrm{~cm}$ and $30 \mathrm{~cm}$.

Dry matter yield for leaves, stems and roots was highly influenced by the type of shrub species (Table 2). Whiles the interaction effect of the species on the leaf dry matter yield was only significant $(\mathrm{p}<0.05)$ between $S$. virosa and the rest of the species, stem dry matter yield was significantly $(\mathrm{p}<0.05)$ higher for $C$. cajan and $S$. mucronata. Generally, Cajanus cajan was significantly $(\mathrm{p}<0.05)$ highest in total dry matter yield while $S$. virosa had the lowest values (Table 2). Cutting height was also observed to have significant $(p<0.001)$ effects on the mean dry matter yields of leaves, stems, and roots (Table 3). In general, the mean dry matter yield of leaves, stems, and roots was significantly $(\mathrm{p}<0.05)$ higher at $60 \mathrm{~cm}$ cutting height compared to those cut at $15 \mathrm{~cm}$ (Table 3).

Table 1. Mean Recovery rate (in days) of shrubs at different cutting heights

\begin{tabular}{lllll}
\hline Species & C. cajan & S. mucronata & T. purpurea & S. virosa \\
\hline Mean & $4.889^{\mathrm{b}}$ & $5.444^{\mathrm{a}}$ & $4.111^{\mathrm{c}}$ & $4.000^{\mathrm{c}}$ \\
Cutting height $(\mathrm{cm})$ & 15 & 30 & 60 & 0.1733 \\
Means & $4.917^{\mathrm{a}}$ & $4.667^{\mathrm{ab}}$ & $4.250^{\mathrm{b}}$ & 0.5082 \\
\hline SEM - standard error of means. LSD- least significant difference. Means in rows with similar letters are not significantly different at 5\% probability & 0.4401 \\
\hline
\end{tabular}

Table 2. Mean Dry Matter Yield (g/plant) of four forage shrubs

\begin{tabular}{|c|c|c|c|c|}
\hline \multirow{2}{*}{ Shrub species } & \multicolumn{4}{|c|}{ Dry matter yield (g/plant) } \\
\hline & Leaf & Stem & Root & Total \\
\hline C. cajan & $37.99^{\mathrm{a}}$ & $45.52^{\mathrm{a}}$ & $32.20^{\mathrm{a}}$ & $116.3^{\mathrm{a}}$ \\
\hline S. mucronata & $38.59^{\mathrm{a}}$ & $47.04^{\mathrm{a}}$ & $24.15^{\mathrm{b}}$ & $108.7^{b}$ \\
\hline T. purpurea & $32.68^{\mathrm{a}}$ & $39.35^{\mathrm{b}}$ & $29.31^{\mathrm{a}}$ & $108.4^{b}$ \\
\hline S. virosa & $39.71^{\mathrm{b}}$ & $36.26^{\mathrm{b}}$ & $24.09^{b}$ & $93.00^{c}$ \\
\hline SEM & 1.042 & 1.220 & 1.140 & 2.200 \\
\hline LSD & 3.056 & 3.578 & 3.344 & 6.440 \\
\hline
\end{tabular}

Table 3. Effects of cutting heights on dry matter yield of four forage shrubs

\begin{tabular}{|c|c|c|c|c|}
\hline \multirow{2}{*}{ Cutting height $(\mathrm{cm})$} & \multicolumn{4}{|c|}{ Dry matter yield (g/plant) } \\
\hline & Leaf & Stem & Root & Total \\
\hline 15 & $30.30^{\mathrm{a}}$ & $36.58^{\mathrm{a}}$ & $24.70^{\mathrm{a}}$ & $91.20^{\mathrm{a}}$ \\
\hline 30 & $37.63^{\mathrm{b}}$ & $40.22^{\mathrm{b}}$ & $26.76^{\mathrm{a}}$ & $104.60^{\mathrm{b}}$ \\
\hline 60 & $43.75^{\mathrm{c}}$ & $49.33^{c}$ & $30.86^{\mathrm{b}}$ & $123.90^{\mathrm{c}}$ \\
\hline SEM & 0.902 & 1.056 & 0.988 & 1.900 \\
\hline LSD & 2.646 & 3.098 & 2.896 & 5.580 \\
\hline
\end{tabular}

SEM - standard errors of means. LSD- least significant difference. Means in colunms with the same superscripts are not significantly different at p<0.05.

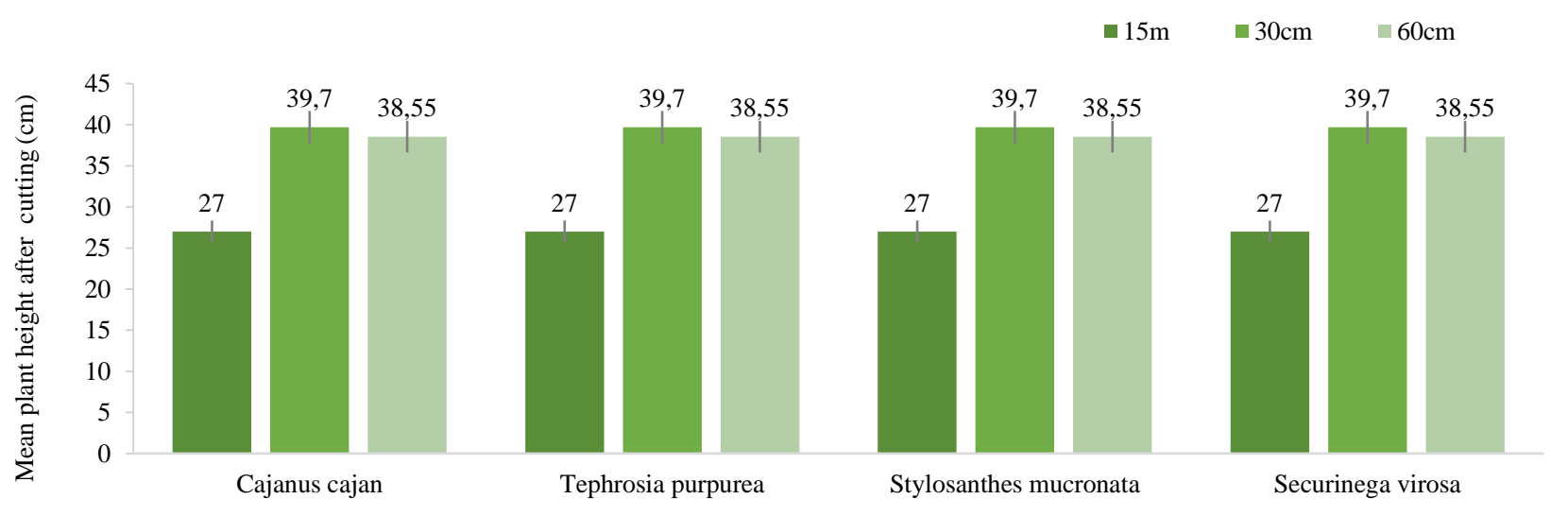

Shrub species

Figure 1. Effects of cutting height on mean plant height 


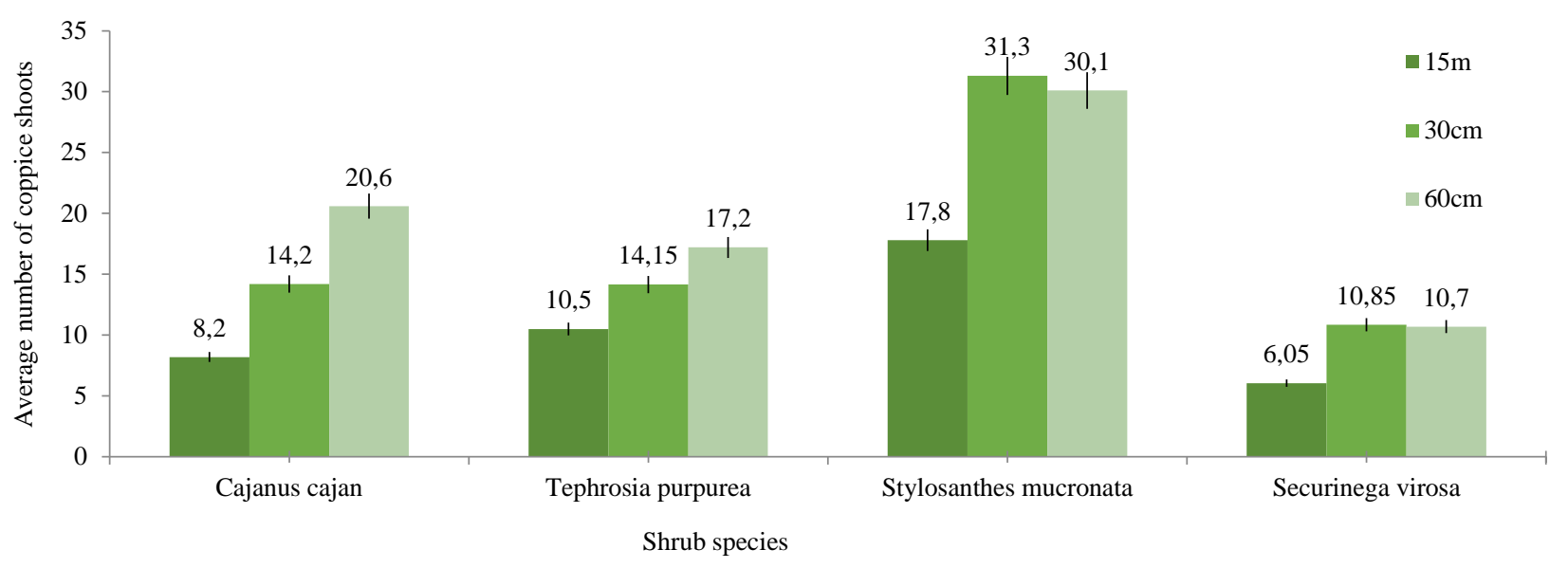

Figure 2. Effects of cutting height on mean number of shoots per plant

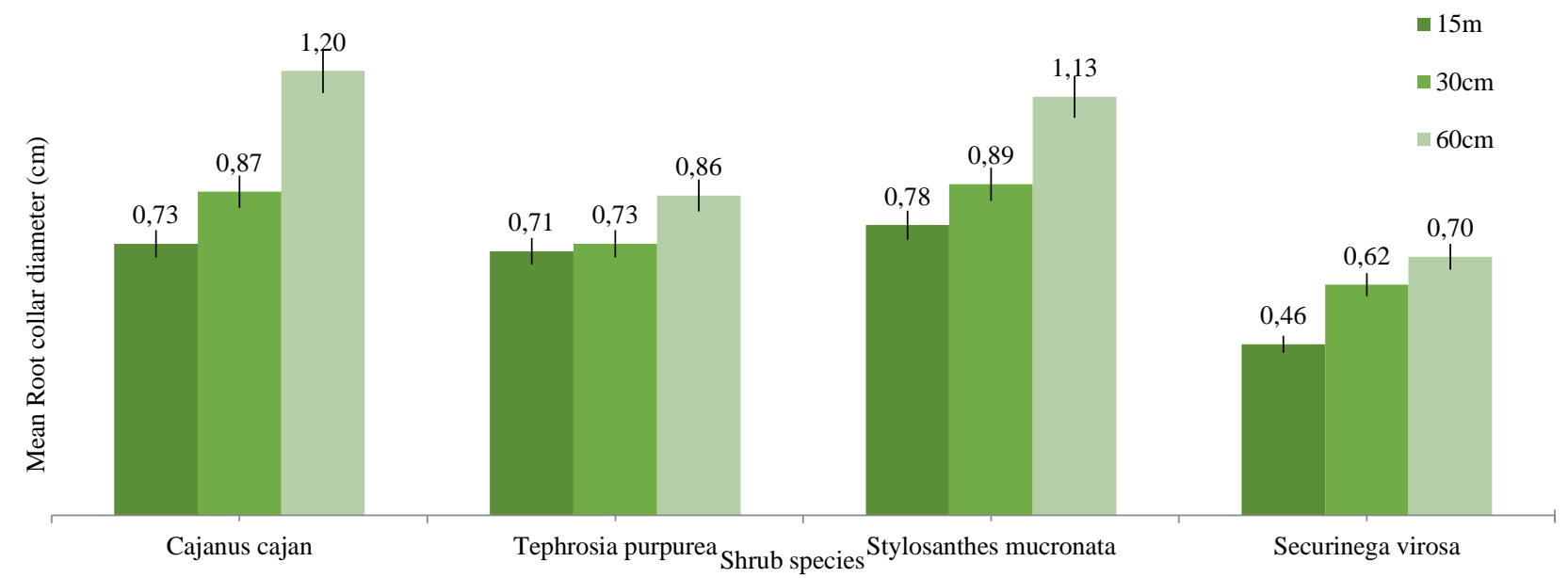

Figure 3. Effects of cutting height on mean root collar diameter

\section{Discussion}

The recovery response of the shrubs was different, probably depending on each shrub's adaptive traits and ontogenetical factors. S. virosa exhibited a rapid sprouting potential while $S$. mucronata showed the lowest recovery rate. Securinega virosa from observation possessed a lignotuber, which probably allowed it to sprout actively and faster. A similar statement was made by Cruz and Moreno (2001), who considered that the lignotuber was against summer drought and low temperature in winter. It was noted that the lignotuber's carbohydrate reserves were mobilized during sprouting, acting as the primary energy source for regrowth at the early stages after cutting (Bowen and Pate, 1993; Van der Heyden and Stock, 1996; Canadell and LòpezSoria, 1998).

The generally low recovery rate registered by plants cut at $15 \mathrm{~cm}$ may be attributable to the limited or total absence of leaves and an inadequate amount of stored carbohydrate reserves. The appearance of new leaves must be initially sustained by stored energy reserves, which may take some time. On the other hand, the high recovery rate recorded by plants cut at $60 \mathrm{~cm}$ could be due to the lenient defoliation, leaving some leaves after cutting and supporting the swift recovery by the current photosynthesis. According to Cruz et al. (2003), replacing stored energy reserves is contingent on the plant's capacity to have efficient photosynthesis, effective growth, and capable of producing excess carbon for storage. Fornara and Du Toit (2007) reported that it is biologically advantageous for plants to have readily available energy sources after interference. Vegetative portions need to be sustained to initiate the buildup of fresh photosynthetic platforms for short recovery (Bowen and Pate, 1993; Luostarinen and Kauppi, 2005; Kozlowski, 2002). Other research noted that a plant requires active meristems and carbon reserves up to the time when fresh shoots are functional and can produce energy (Kabeya and Sakai, 2005; Bond and Midgley, 2001).

Clipping height of plants is a vital management consideration in forage production systems because it has a significant influence on the rate of regrowth, biomass production, quality, and survival of forage plants (Tudsri et al., 2002; Wadi et al., 2004; Yolcu et al., 2006). The results of the study revealed that cutting had a diverse influence on the growth of the shrubs depending on the level of cut. It was noticed from the results that the different shrub species responded differently to the cutting experiment for all the growth indices measured except for plant height where similar responses were observed. The different responses exhibited by the shrubs could be attributed to the differences in genetic characteristics and the ability to tolerate shocks such as imposed by cutting. Generally, stem height, the 
number of coppice shoots, and root collar diameter increased with increasing height of cut. Plants cut at $15 \mathrm{~cm}$ from the ground gave the lowest regrowth and this probably could be because the plants were adversely affected and could not readily recover because of low carbohydrate reserves (Caetano et al., 2013). The poor regrowth of plants at low cutting height could also be attributable to a lack of regrowth sites (buds), which can vary from species to species. In the presence of good bud development, regrowth will be sustained on the rapid mobilisation of carbohydrate reserves. Studies on Macroptilium lathyroides L. (Tobisa et al., 2003), Panicum virgatum L. (Trocsanyi et al., 2009), and Pennisetum purpureum Schum. (Wijitphan et al., 2009) have shown that bud initiation, shoot growth, and forage yield was reduced due to low cutting height. Low clipping heights remove the apical meristems and tissues that store starch.

The relatively high regrowth rate exhibited by plants cut at $30 \mathrm{~cm}$ and $60 \mathrm{~cm}$ could probably be due to the efficiency of the root system to provide a greater amount of stored carbohydrate reserves and other photosynthates (Meuriot et al., 2005). When cutting height is increased, there will be a substantial number of residual leaves on the plants and this may result in greater available energy reserves leading to a shorter lag phase.

Mean dry matter yields varied among the shrubs and the differences might have reflected variations in growth habits, residual buds, leaf area index, and stored carbohydrates (Caetano et al., 2011). It was suspected that $S$. virosa had high efficiency to produce sufficient carbohydrate reserves to support regrowth (Caetano et al., 2011).

Generally, the leaf, stem, root and total dry matter yields of all the shrubs studied also increased with cutting height. This was because the root systems and the remaining leaves on the plants have high efficiency to produce sufficient carbohydrate reserves to support regrowth. The findings of this study agree with that of Oppong (1998) who observed high total dry matter of Salix matsudana x alba cut at $80 \mathrm{~cm}$ and $120 \mathrm{~cm}$ than at $30 \mathrm{~cm}$.

Similar observation made by Nduwayezu et al. (2005) indicated that foliage biomass yields of Senna singueana under inter-cropping system increased with lopping height to $75 \mathrm{~cm}$ but declined at a higher cutting height. Karim et al. (1991) also observed the highest dry matter yield of Leucaena leucocephala at $75 \mathrm{~cm}$ clipping height.

Several researchers concluded that higher lopping heights of plants, particularly woody species, produce higher dry matter yield (Blair et al., 1990; Costa and Oliveira, 1992; Hairiah et al., 1992). Studies by Battad et al. (1993) endorsed $50 \mathrm{~cm}$ as the most appropriate cutting height for better dry matter yield. It was observed from this study that clipping at $60 \mathrm{~cm}$ produced more buds and a greater number of new shoots per plant than clipping at $15 \mathrm{~cm}$. These findings confirm with other studies, which concluded that cutting woody species at various heights affects vegetative growth with better shoot development observed at higher cutting heights (Chourio et al., 1997; Bouayad et al., 1998; Gaddanakeri et al., 1993; Tarawali et al., 1996).

\section{Conclusions}

The recovery rate and regrowth of shrub species after cutting are critically dependent on their sprouting capabilities and the number of stored carbohydrate reserves. Recovery response to cutting height is species-dependent and high cutting heights resulted in rapid recovery. Cutting height significantly influences plant growth rate and dry matter yield.

\section{Funding}

The research was solely sponsored by the authors.

\section{Acknowledgement}

Mr. Timothy Khan Aikins and Mr. Eric Adjei Lawer's efforts in reading through the work for grammatical and statistical errors are worth acknowledging. We are very grateful.

\section{References}

Alados, C., Barroso, F.G., Garcia, L., 1997. Effects of early season defoliation on above-ground growth of Anthyllis cytisoides, a Mediterranean browse species. Journal of Arid Environments, 37: 269-283.

Allanah, N.C., Lonnie, A.W., 1998. Effects of shoot apex removal and fruit herbivory on branching, biomass and reproduction in Verbascum thapsus (Scrophulariaceae). The American midland naturalist, 140(1): 42-54.

Bassiri, M., Fatemi, S., Vahabi, M.R., Yeganeh, H., 2010. Interaction effects of water stress and harvest intensity and frequency on productivity of Atriplex lentiformis (Torr.) S. Wats and Nitraria schoberi L. Rangeland Iran, 4(2): 276-287.

Battad, Z.M., Trung, L.T., Ttengco, P.L., Zamora, O.B., Atega, T.A., 1993. Yield performance and nutritive value of hedge lucerne (Desmanthus virgatus $\mathrm{L}$. Willd.) under different cutting regimes. Philippine Journal of Crop Science, 18(1): 24.

Belay, D., Getachew, E., Azage, T., Hegde, B.H., 2013. Farmers' perceived livestock production constraints in Ginchi watershed area: Result of participatory rural appraisal. International Journal of Livestock Production, 4(8): 128-134.

Blair, G., Catchpoole, D., Horne, P., 1990. Forage tree legumes: Their management and contribution to the nitrogen economy of wet and humid tropical environments. Advances in Agronomy, 44: $27-54$

Bond, W.J., Midgley, J.J., 2001. Ecology of sprouting in woody plants: the persistence niche. Trends in Ecology and Evolution, 16(1): 45-51.

Bouayad, A., Achhal, A.E., Fechtal, M., 1998. Estimation of biomass and essential oil production by Artemissia herba-alba Asso in skoura pasturage (Ouarzazate Province). Anales de la Recherche Forestiere au Maro $c$, 31: 17-25.

Bowen, B.J., Pate, J.S., 1993. The significance of root starch in postfire shoot recovery of the resprouter Stirlingia latifolia $\mathrm{R}$. Br. (Proteaceae). Annals of Botany, 72: 7-16.

Caetano, H., Oliveira, M.D.S.D., Freitas Júnior, J.E.D., Rêgo, A.C.D., Rennó, F.P., Carvalho, M.V.D., 2011. Evaluation of corn cultivars harvested at two cutting heights for ensilage. Revista Brasileira de Zootecnia, 40(1): 12-19.

Canadell, J., Lopez-Soria, L., 1998. Lignotuber reserves support regrowth following clipping of two Mediterranean shrubs. Functional Ecology, 12: 31-38.

Catchpole, D.W., Blair, G., 1990. Forage tree legumes. I. Productivity and $\mathrm{N}$ economy of Leucaena, Gliricidia, Calliandra and Sesbania and Tree/Green Panic Mixtures. Aust J Agric Res, 41: 521-530.

Chourio, J., Colina, V., Clavero, T., Razz, R., Castro, C., 1997. Effect of defoliation on biomass production of Clitoria ternatea (L.) DNE. Cuban Journal of Agricultural Science, 31: 113-117.

Costa, N., Oliveira, A.C., 1992. Cutting height affects Cajanus cajan yield and protein content. Nitrogen fixing tree research reports, 10: 119-120.

Cruz, A., Perez, B., Moreno, J.M., 2003. Plant stored reserves do not drive resprouting of the lignotuberous shrub Erica australis. New Phytologist, 157: 251-261. 
Cruz, A., Moreno, J.M., 2001. No allocation trade-offs between flowering and sprouting in the lignotuberous, Mediterranean shrub Erica australis. Acta Oecologica, 22: 121-127.

Dun, E.A., Ferguson, B.J., Beveridge, C.A., 2006. Apical dominance and shoot branching. Divergent opinions or divergent mechanisms. Plant Physiology, 142(3): 812-9.

Ella, A., Jacbsen, C., Stur, W.W., Blair, G., 1989. Effect of plant density and cutting frequency on the productivity of four tree legumes. Tropical Grassland, 23: 28-34.

Fornara, D.A., Du, T.J.T., 2007. Browsing lawns? Responses of Acacia nigrescens to ungulate browsing in an African Savanna. Ecology, 88(1): 200-209.

Gaddanakeri, S.A., Gumaste, S.K., Hunshal, C.S., 1993. Effect of subabul (Leucaena leucocephala)-live bund on growth and yield of companion crop of sunflower (Helianthus annuus). Indian Journal of Agronomy, 38: 598-602.

George, F.F., 2015. Assessment of leaf biomass production of selected deciduous indigenous browse shrub in semi-arid ecological zone of Mwanga District, Tanzania. Master of science Thesis, Sokoine University of Agriculture, Morogoro, Tanzania.

Hairiah, K., Noordwijk, M., Van Santoso, B., Syekhfani, M.S., 1992. Biomass Production and root distribution of eight trees and their potential for hedgerow intercropping on an ultisol in southern Sumatra. Agrivita, 15: 54-68.

Hélio, C., Eloisa, S., Diego, G., Marco, B., Ângela, M.L., Ana Luiza, B., Aline, L., Antonio, F., 2019. Effects of Zinc Sulfate or Propylene Glycol on Intake, Digestibility, and Forage Selection by Grazing Sheep in a Semi-Arid Region During the Rainy Season. Animals, 9(11): 1-14.

International Atomic Energy Agency., 2010. Improving Livestock Production Using Indigenous Resources and Conserving the Environment. IAEA-TECDOC-1640, Vienna-Austria.

Iqbal, M.A., Iqbal, A., Akbar, N., Khan, H.Z., Abbas, R.N., 2015. A study on feed stuffs role in enhancing the productivity of milch animals in Pakistan-Existing scenario and future prospect. Global Veterinaria, 14(1): 23-33.

Kabeya, D., Sakai, S., 2005. The relative importance of carbohydrate and nitrogen for the resprouting ability of Quercus crispula seedlings. Annals of Botany, 96: 479-488.

Karim, A.B., Rhodes, E.R., Savill, P.S., 1991. Effect of cutting height and cutting interval on dry matter yield of Leucaena leucocephala (Lam) De Wit. Agroforestry Systems, 16: 129137.

Kebebe, E., 2019. Bridging technology adoption gaps in livestock sector in Ethiopia: An innovation system perspective. Technology in Society Elsevier, 57: 30-37.

Kozlowski, T.T., 2002. Physiological ecology of natural regeneration of harvested and disturbed forest stands: Implications for forest management. Forest Ecology and Management, 158(3): 195-221.

Krishna, M.K., Munegowda, M.K., 1982. Effect of cutting frequency regimes on the herbage yield of Leucaena. Research Reports, 3: 31-32.

Larbi, A., Khatib-Salkini, A., Jamal, P.B., Iniguez, L., 2009. Shrub yield and fodder quality variations in a non-tropical dryland environment in West Asia. Agroforestry Systems, 75(2): 147155.

Luostarine, K., Kauppi, A., 2005. Effects of coppicing on the root and stump carbohydrate dynamics in birches. New Forests, 29(3): 289-303

Meuriot, F., Decau, M.L., Morvan-Bertrand, A., 2005. Contribution of initial $\mathrm{C}$ and $\mathrm{N}$ reserves in Medicago sativa recovering from defoliation: impact of cutting height and residual leaf area. Functional Plant Biology, 32: 321-334.
Nduwayezu, J.B., Lulandala, L.L.L., Chamshama, S.A.O., Mugasha, A.G., 2005. The effect of cutting height of Senna singueana (Del.) lock. In mixed intercropping system on foliage biomass production and maize yield in Morogoro Tanzania. Journal of Agronomy, 4: 323-328.

Oppong, S.K., 1998. Growth, Management and Nutritive value of Willows (Salix Spp.) and other Browse species in Manawatu, New Zealand. Ph.D. Thesis, Massey University, Palmerston North, New Zealand.

Parissi, Z.M., Nastis, A.S., 2004. Regrowth of two ligneous species as affected by clipping intensity and frequency. In: Ferchichi A. (comp.), Ferchichi A. (collab.). Réhabilitation des pâturages et des parcours en milieux méditerranéens. Zaragoza CIHEAM, 357-360.

Pathak, P.S., Rai, P., Deb, R., 1980. Forage production from koobabool Leucaena leucocephala (Lam.) de Wit.). Forage Research, 6: 83-90.

Stür, W.W., Shelton, H.M., Gutteridge, R.C., 1994. Defoliation management of forage tree legumes. In: R.C. Gutteridge and H.M. Shelton (eds). Forage Tree Legumes in Tropical Agriculture. CAB Int Wallingford UK.

Tarawali, G., Iji, P.A., Chionuma, P.C., Obot, U., 1996. Herbage yield and quality of Gliricidia sepium under different cutting heights and defoliation frequencies. Agroforestry Systems, 34: 315-326.

Tobisa, M., Tajiri, K., Murakami, K., Shimojo, M., Masuda, Y., 2003. Effects of growth temperature and cutting height on regrowth of tropical forage legume phasey bean (Macroptilium lathyroides (L.) Urb.). Grassland Science, 49: 149-157.

Trócsányi, Z.K., Fieldsend, A.F., Wolf, D.D., 2009. Yield and canopy characteristics of Switch grass (Panicum virgatum L.) as influenced by cutting management. Biomass and Bioenergy, 33(3): 442-448.

Tudsri, S., Jorgensen, S.T., Riddach, P., Poopakdi, A., 2002. Effect of cutting height and dry season closing date on yield and quality of five Napier grass cultivars in Thailand. Tropical Grasslands, 36: 248-252.

Van der Heyden, F., Stock, W.D., 1996. Regrowth of a semiarid shrub following simulated browsing: the role of reserve carbon. Functional Ecology, 10: 647-653.

Wadi, A., Ishii,Y., Idota, S. 2004. Effect of cutting interval and cutting height on dry matter yield and overwintering ability at the established year in Pennisetum species. Plant Production Science, 7: 88-96.

Wijitphan, S., Lorwilai, P., Arkaseang, C., 2009. Effect of cutting height on productivity and quality of king napier grass (Pennisetum purpureum cv. King Grass) under irrigation. Pakistan Journal of Nutrition, 8: 1244-1250.

Yolcu, H., Mustafa, M., Serin, Y., 2006. Effects of early cutting time and stubble height on yield and quality in lucerne. New Zealand Journal of Agricultural Research, 49: 201-206.

Ziblim, A.I., Agyapong, R.A., Aikins, T.K., 2016. Assessing the biomass production and nutritive value of Kenaf (Hibiscus Cannabinus) at various stages of growth. UDS International Journal of Development, 2(2): 26-36.

Zinati, G.M., 2001. Biomass yield and flower production in Sunn Hemp, effect of cutting the main stem. Institute of food and Agricultural sciences Tropical Research and Education Centre, University of Florida, Homestead, FL 33031, United State, 83104. 